\title{
A Survey On The Use of Blockchain For The Internet Of Things
}

Tanweer Alam ${ }^{1}$

${ }^{1}$ Faculty of Computer and Information Systems, Islamic University of Madinah

October 25, 2021

\section{Hosted file}

ijeie-2021-v13-n3-p119-130.pdf available at https://authorea.com/users/442659/articles/ 542871-a-survey-on-the-use-of-blockchain-for-the-internet-of-things 